\title{
Manchuria and the CER line as Historically Formed in 1917 Foreign Centers of Russian Settlement on the Territory of North-Eastern China
}

\author{
Igor V. Chapygin* \\ Irkutsk State University \\ 1 Karl Marx Str., Irkutsk, 664003, Russia
}

Received 14.09.2014, received in revised form 24.10.2014, accepted 05.11.2014

The paper considers Manchuria and the CER (Chinese Eastern Railway) as a historically formed in 1917 foreign centers of Russian settlement on the territory of North-Eastern China. Through a brief analysis of the relations between Russia and China in the period from 17th to the beginning of 20th centuries the author shows periods of active development on the territory of the neighboring state made by Russians citizens.

Keywords: Manchuria, North-East China, the Cossacks, the state border Treaty, Harbin, CER.

Research area: History.

The appearance of the Russian population in Manchuria (an established name of the North-East of China) was preceded by a number of historical events and processes, having taken place long before the revolution of 1917, which led to the Civil war and became the cause of a mass flight of military and civilian population of the defeated White Army from the regions of Siberia and the Far East onto its territory.

In the $17^{\text {th }}$ century, the exploration of Siberia and the Far East by Russian pioneers opened a new stage of the epoch of the Great geographical discoveries and contributed to the transformation of Russia into a major Pacific maritime power. Russia showed serious interest in its Eastern neighbor, China, with which it carried out connection mainly with the mediation of the Central Asian merchants till the 1650s
[Sladkovskii]. The Treaty of Nerchinsk of 1689 marked the beginning of official relations between Russia and China. Since 1693, the Russian stateowned caravans were quite regularly sent from Transbaikalia (Trans-Baikal) to China (in the period 1693-1719 there were organized ten caravans) [Miasnikov]. Nerchinsk had undeniable geographical advantages for Russian-Chinese trade compared to Tobolsk and Tomsk, and after the normalization of the situation in the TransBaikal section of the border this region became the main direction for the maintenance of the ties with China. In the text of the Treaty of Nerchinsk it was accurately told as such: "And wars and bloodsheds from both sides ... should not take place" [Kurz]. It meant that any conflicts had to be resolved by negotiations. It is necessary to add that this principle became the basis of the further

(c) Siberian Federal University. All rights reserved

* Corresponding author E-mail address: IGOR VCH@mail.ru 
relations and arrangements, and trade played very important role in economic rapprochement of two neighboring states, in mutual acquaintance with customs of their people.

By mid-20s of the $18^{\text {th }}$ century the parties proceeded with the establishment of state borders, emerging with the development of bordering territories by people, involved in structuring the territories of Russia and China. On 20 August 1727 the two countries signed the Treaty of Bura, and later, on 21 October 1727 there was concluded the Treaty of Kiakhta. After they had been signed, trade between the two countries was streamlined, and its volume increased significantly compared with the previous period.

The needs of the defense of the southern and eastern borderlands and relatively small maintenance costs compared to regular parts of the territory prompted the Russian government to preserve the division of officers of the Cossacks in the border regions of southern Russia, Siberia and the Far East. In this period, in fact, Transbaikalian Cossacks did the first evolutionary step. According to the census 1721 only in Nerchinsk office for 476 Cossack officers there were revealed 1410 relatives who had the formal right of priority in being called on service, what urged the growth of the Cossack population. Thus, the hereditary principle of Cossack life appeared, and that was the beginning of the appearance of the Cossack settlement in Transbaikalia, as organized, mobile military forces of border protection and the maintenance of internal order. In 1727, on the border with China there were established 18 guards, 2 outposts; to 1728 their number increased to 31 , and the construction of fortresses began.

In 1763 - 1764 relations with China exacerbated. The reason was unsuccessful appeal of Chinese Emperors to acceded to the Russian throne Catherine II who offered to exchange embassies. The Chinese side was offended by the phrase of Catherine: “...If you do not observe the placidity, loyalty, peace, then we have other measures". In reply the Russian government was sent the following words: "...is it possible to Chinese emperors to be equal to someone from autocratic rulers, and, least of all, a woman, who rules Russia?" [Kurts]. In 1764 the Chinese ceased the trade in Kiakhta, expelled Russian merchants and broke diplomatic relations. Thus, the intentions of Annex of Mongolia and the lands along the Amur River to Russia did not realize. By 1774 the number of posts and guards on the border with China had grown to 74 units covering border of 2,343.5 versts (a Russian unit of distance equal to 1.067 kilometers (0.6629 mile)). Most of them gradually turned into crossborder settlements and villages.

Interest in the "Amur issue" became relevant again in the $19^{\text {th }}$ century, after the UK had achieved the opening in China of the five ports for trade relations. The demise of Kiakhta trade was impending, and it brought multimillion-dollar profits to Russia and China. Consistent position of the Russian government, criticizing Britain for waging opium war (1840 - 1842 and 1856 1860) against China, and the strict prohibition of the import into China opium caused appreciation of the Qing dynasty. All this could not but affect the nature of Russian-Chinese relations and created the necessary external preconditions for a diplomatic solution of the issue about the demarcation of Priamurye and Primorye (Primorsky Krai).

An important role in the practical solution of this problem belonged to the General-Governor of Eastern Siberia N.N. Murav'iov. He also played a major role in the creation of the Transbaikalian Cossack troops in 1851, as a shield from possible attacks of China.

Because in Russian government circles there was established the impression that the Amur River in its lower tributaries was not navigable and lost in the sands, and Sakhalin was a Peninsula 
locked by his isthmus the output of the modern Tatar Strait to the South, the value of the Amur and Sakhalin to Russia was quite questionable. N.N. Murav'iov in the summer 1849 assisted the organization of the expedition of Lieutenantcaptain (later Admiral) G.I. Nevelskoy, who ascertained full availability of the Amur River for marine vessels and confirmed the status of Sakhalin island, separated from the mainland by the deep-sea Strait. The value of the Amur River for Russia in connection with the release of the river to the Pacific Ocean increased significantly.

Due to Russian-Chinese Treaty of Aigun signed on May 16, 1858, and ratified by the governments of both countries, the left bank of the Amur was recognized as belonging to Russia and the right (to the Ussuri River) to China. The decision on belonging to Primorye was postponed. These lands were recognized as temporarily staying in common ownership. Under the contract only Russian and Chinese vessels were allowed to go along the rivers Amur, Songhua and Ussuri. In 1858 , Ust-Zeya military post was transformed in Blagoveshchensk, which became the center of the newly established Amur region, downstream the Amur a military post Khabarovka (future Khabarovsk) and other Russian villages were founded. For the protection of new south-eastern border for the foundation and providing of mail messages on the Amur and Ussuri Rivers' banks in 1858 there were established Amur Cossack troops, the core of which consisted of Transbaikalian Cossacks who had been resettled by the government in Priamurye and Primorye. The Amur Cossack army had been guarding the Russian border along the Amur River.

The main purpose of the Treaty of Aigun, which was the demarcation of the Amur River and the recognition of its left bank as Russian territory, was achieved. European States, especially Britain and France, and also China were forced to accept the settlement of the Amur
River as an accomplished fact. Almost parallel to the conclusion of the Treaty of Aigun the signing of the Russian-Chinese the Treaty of Tientsin took place, and it did not contradict the already signed the Treaty of Aigun, outlining the wide program for the refinement of the boundary line between the two countries, its description and mapping of adjacent areas.

On November 2, 1860, there was signed the Treaty of Beijing, according to which the border was set on the whole eastern area of the rivers Amur and Ussuri, Songacha, lake Khanka and forth in the mountains to the Tumen River (border with Korea). In the western area the agreement scheduled the general direction of the border along lake Zaisan and Issyk Kul (then it has been refined by Chuguchak Protocol of 1864) [Lukin (ed.)]. Joining the South-Ussuri region with its convenient harbours and waterways to Russia allowed its government in the second half of the $19^{\text {th }}$ century resuming settlement and economic development of the Far East. The colonization of the South-Ussuri region - the most southern part of the Primorye region - started in 1860 with the creation of military posts: Vladivostok, Novgorod, Novokievsk and other.

Aigun and Beijing treaties, concluded after peaceful negotiations, completed the long process of demarcation of the lands of Russia and China in the Far East and thus summed up the important stage in the history of their relations in the $17^{\text {th }}$ $19^{\text {th }}$ centuries

In the middle of the $19^{\text {th }}$ century rumors about rich gold deposits found in the neighboring Manchuria came from China in the Amur region. From this time in the near-Argun areas of China there began to emerge a mixed Russian-Chinese settlement of miners. This free gold mining reached an especial expansion in the 1880s, which was enhanced by a very liberal regime of the Russian-Chinese border. In principle, bilateral agreements did not forbid the transition 
of the Russian-Chinese border by people of both empires anywhere. Russian researcher who crossed the border in Hulunbuir in 1881, noted: "Border residents are passed through the border quite freely, and no formalities follow" [Manakin].

Manchuria was the hugest and the richest region of China. Its area -1.230 .673 sq. $\mathrm{km}-$ was twice as much as the territory of the neighboring Transbaikalia and was equal to the Amur and Primorye areas, combined. Manchuria corresponded to the territory of two France and was larger than the area of France, Britain and Italy put together, three and a half times more than the size of Japan.

What is more, Manchuria had substantial natural resources. A considerable part of territory in the North and the East was covered with pristine taiga rich in fur game; on the West there was the steppe with exceptionally favorable conditions for cattle breeding: there were tens of thousands of cattle, sheep, horses and camels; the South with its fertile soils and warm climate was the area of developed agriculture. Manchuria was famous for its ginseng, antlers and grass "ula" used for insulation of shoes. Here people successfully searched for gold and pearls; hunters hunted annually up to 10 million pheasants and 1 mln. skins of tarbagan [Serebrennikov].

"In the summer of 1883 in Priamurye rumors began to spread about the gold that was found on the territory of China on the river with a local name Gelta. This river, only about $15 \mathrm{~km}$ long, was the tributary of Albazikha (the right river tributary of the Amur River). The Chinese name for it is Mohe. Here gold miners rushed. There was founded a settlement, where Russians and, of course, Chinese lived, and also Koreans, and other nations. It was a motley crew: indigenous Siberians, exiled settlers, runaway criminals, hunters looking for easy money. The number of miners was rising rapidly, in a year there were already 10 thousand people. These people of new Amur Libertines - did not recognize neither the Russians nor the Chinese authorities, let along any bosses, any laws. By the end of 1885, its population was about 20 thousand, including 500 Chinese and over 100 Koreans. Here there were shops, restaurants, hotels, gambling houses and brothels, in which fortunes were spent, hospitals, even banks and a chapel. Geltugintsy managed to produce approximately 500 pounds of gold, most of which went to China" [Melikhov]. These places were called "Amur California", or "Geltugin Republic". China was bothered by the influx of Russians into its territory, and sent troops to Mohe. The Russian government issued a special decree to stop the transition of its citizens across the Chinese border for the production of gold, and sent people specially to return the miners back. However, more than a thousand of them remained deaf to the demands of the government and continued to hide, what caused the re-use of military force by the Chinese. Settlement of Geltugintsy was swept away from the face of the earth. In October 1892 about a hundred of Russian miners crossed the border and infiltrated into the area between the rivers Maureen-Goal and Derbul for the production of gold. This caused a new armed conflict, the Russians had to leave 23 buildings, 8 houses covered with birch bark, 123 pits and 50 mines [Tarasov].

The existence of illegal settlements of Russian gold miners in Barga (North-Western Manchuria) is the first bright stage in the history of development of territories of the neighboring state.

By the beginning of 1890 the Russian government decided to build the Great Siberian railway, which was designed to link the distant outskirts of the Russian Empire with the central regions of the country. The matter was accelerated by beginning military events in the Far East. In1894 - 1895 there was the outbreak of the Sino- 
Japanese war, which ended in a terrible defeat of China and demonstrated the seriousness of Japan aggressive policy. The military buildup of Japan in the Far East took place in the conditions when Russian Far Eastern regions remain underpopulated, their military security was not provided. The events of the Sino-Japanese war demonstrated the need to strengthen Russia in the East and remote Primorye and Priamurye from the central regions of the country. The importance of connecting Vladivostok by rail with the European Russia in the shortest possible time became clear.

In 1896, there was signed the secret RussianChinese Treaty of Alliance against Japan and the construction of the CER (Chinese Eastern railway), which passed through North-Eastern China and was to directly connect Siberian railway (from the city of Chita) with Vladivostok. After the Treaty they signed the convention on granting Russia with ports Lüshunkou (Port Arthur) and Dalian (Dalny in Russian), located on the Liaodong Peninsula, from the Qing empire in rent [10]. Then in 1898 there was made a decision on construction temples there. In Port Arthur devoted to the Prelate Nikolay, and in Dalny - the temple devoted to the martyr Aleksandra, "whose days of celebration coincide with joyful for all Russia name days of the Sovereign Emperor and Empress" [RSHA].

The purpose of this paper does not allow including detailed analysis of the reasons and grounds for the construction of the CER, conditions of its operation, but one thing is clear, in favor of "Manchurian options" there were found indeed economic considerations, as well as significant political and strategic goals. It is the construction and operation of the road what gave an impetus to the further development of this territory of the Qing Empire and marked the beginning of the second stage in the history of the Russian Diaspora in Manchuria.
Preliminary work on the construction of the CER started in 1897 in several directions simultaneously, including the one from Chita to the East, to meet with the builders who were going from Vladivostok. In 1900 for the construction of the station, near which Chinese cities of Manchuria subsequently appeared, 130 Russian workers and engineers arrived and more than 4000 Chinese workers arrived from the province of Shandong and Hebei.

Thorough policy of the administration in relation to the local population, the full recognition and support of its rights and interests led to a rapid growth of trust of the Chinese population to the builders of the CER. In their relations there was created an atmosphere of friendship and cooperation, what were characteristic for all subsequent long period of joint exploitation of the railway and the life of the Russian colony in Manchuria in the Chinese environment. It is worth thinking about the following fact. The band alienation of the CER never was a foreign settlement in China, what was usual in all its major cities where foreigners settled in isolation from the mass of ordinary Chinese, they lived only according to their own laws, had their own police and consular court. Here throughout North Manchuria, Russian and Chinese people, as the same alien kind to most areas, settled near each other, had the same rights and faced the same difficulties in settling in new places. Having data on the history of Manchuria, it can be proved that the life of the Russian and Chinese population in the alienation zone of the CER during more than 50 years of "Russian episode" in Manchuria (except for events of July-August 1900 - the boxer rebellion), took place without any incidents, without conflicts, especially on racial or religious grounds. Certainly, there were minor disputes and conflicts that were resolved through institutions, which were called Tszyaoshetszyuy (departments for mutual communication, or diplomatic 
bureaus, created by engineer A.I. Iugovich). They had a mixed local Russian-Chinese board that considered all misunderstandings and issues directly or indirectly related to the needs of the road, as well as the issues of the Russians and Chinese who lived in the alienation zone. In these offices there were representatives of local Chinese administration and from the Russian part - people appointed by the chief engineer. The bureau was a mixed court, where mutual claims of Russian and Chinese subjects were solved. Strict rule of law advantageously distinguished these institutions from the Chinese judicial bodies Yamens, where the sentence could be bought for money.

It is known that the CER necessarily bought from private owners fields alienated for the needs of the roads. Width of such land on the routes between stations was established as 40 Russian fathoms (20 in each way), but was actually less: 15 fathoms on the one side and 18 - on the other (respectively about $32 \mathrm{~m}$ and a little more than 38 m). 50 deasiatinas (tenths) of land ( 54.5 ha) were alienated for the large station, for the other kinds and patrols - up to 30 desiatinas (32.7 ha).

Initially land acquisition was under jurisdiction of the Management of the Road of the Special Department of Alienation, which existed until 1912, when its functions were transferred to the Land Department. Mixed bureaus, Tszyaoshetszyuy, checked and confirmed every act on alienation of land plots, being, thus, representatives of the interests of the Chinese side. These organizations were the active link that united the Russians and Chinese in the alienation zone. They existed until 1920, having survived after the collapse of the Russian Empire.

Russian road builders, as all the foreigners in China, had the right of extraterritoriality. In accordance with the clause 6 of the "Contract on construction of CER", in the alienation zone there were gradually created all the usual institutes of the Russian administrative system: the police, where the Russians and the Chinese were serving, the court; also protection of roads was provided by civil service. In the conditions of development in Manchuria of hónghúzi (bandits), the problem of personal security of the CER, surveyors and builders was extremely urgent. The company of the CER, according to the Charter, should itself take care of the protection of the road. Cossacks, who served on the basis of voluntary recruitment, were considered as the best contingent for such protection. They made the Protective Watch of the CER, originally of five horse divisions.

Yihetuan Movement (the Boxer Rebellion), lasted by the summer of 1900 on the territory of Manchuria, violated the further systematic construction of the CER and forced the Russian builders to go back to Transbaikalia. For the protection of roads regular Russian troops entered Manchuria. During the military operations the Russian army was forced to remove the Chinese border posts along the Argun River, and China lost the ability to guard the border, so the mass resettlement of Russian Cossacks began, they went to the right (Chinese) bank of the border river due to the lack of land for pastures and hayfields. Although in Eastern Transbaikalia there were no landlords economy, but about 10 million desiatinas of land belonged to the Imperial house of the Romanovs - the so-called Cabinet's lands, which Cossacks were forced to rent. District of Barga, the so-called ThreeRiver Delta (the basin of the right tributaries of the Argun - Gan, Derbul and Khaul), was known for Transbaikalian Cossacks and attracted them by their natural wealth. Since the end of the $19^{\text {th }}$ century, they were moving to the Three-River Delta their flocks and herds for grazing, storing up here hay and plowed the virgin lands. They found subsidiary earnings, hunting for prey and fur animals in taiga areas of this region, put dugout huts there. Later Cossacks began to settle there permanently, from 1906-1907, but 
particularly intensively after the outbreak of Civil war in Siberia and the Far East (1918-1922). Thus, at the beginning of the $20^{\text {th }}$ century, the land issue was the basis of Russian emigration to the Chinese, right bank of Argun.

One of the consequences of the events in Manchuria during the Boxer Rebellion was the reorganization of the Protective Watch and its inclusion on 19 January, 1901, in the composition of the Special District of the Amur Separate Corps of Border Guards, bringing the number up to 25 thousand people of all troops - cavalry, infantry and artillery. The squad was directly subordinated to the Minister of Finance. The head of the district until 1902 was General M.K. Diterikhs, (whose name was later linked to the final phase of the Civil War in the Soviet Far East; also in their time in Protective Watch of the roads served such people as: A.I. Guchkov, A.I. Denikin, L.G. Kornilov famous political and military figures of Russia). In the future, Russian government intended to solve the problem of providing the CER with security by the establishment of military settlements in the alienation zone. The author of the idea was Amur Governor-General Grodekov. In the memo addressed to the Emperor, he suggested: "to settle the alienation strip (the CER) by Russian element, capable to find the force at least for the initial line protection from armed attacks, as the Protective Watch guards, scattered throughout the vast territory of CER, are numerically insufficient in each paragraph of security" [Tarasov]. Nicholas II approved of the initiative and instructed the Defense Ministry, the ministries of Finance and Agriculture to develop the project of creation of Cossack villages and soldiers suburbs along all branches of the CER. Originally it was supposed to use the same Transbaikalian Cossacks and the lower ranks of the expeditionary corps of the regular army awaited to be discharged to the reserve. They had to be allocated with land, that in 1903-1905 was received by Russia as a concession for the rights of long-term lease at a rate of 3,000 desiatinas at each station, including the Western line. People, who wanted to get it, were not great in number, although the Company of the CER annually allocated for these needs 200 thousand rubles for the start, and state exempts them from the land rent for ten years. By 1905 throughout the Manchurian army there were registered only 2,518 such settlers. At the same time Russians moved to the right bank of Argun and got engaged in the usual production of gold and began to break fresh grounds and to graze cattle. By 1907, only in the Argun banner Barga (Western branch of the CER) there were 1,000 households, in which five thousand Russians lived.

By the time of launching the CER, the total extent of its lines with branches, stations and tracks was $3,189 \mathrm{~km}$. Very soon 107 stations became large developing villages. The road had built there 294,061 square meters of living quarters by 1903 (the year when the CER started to work), and by $1911-606,587$ sq. m, i.e., 467,9 sq. $\mathrm{m}$ per $1 \mathrm{~km}$ of the main road. Total number of employees on the road was counted in 1903 as 39,112 people, of which 18,123 were Russians, 20,948 - Chinese, 17 - Austrians, Italians, Swiss and Turkish, 17 Japanese and 9 - Koreans. The cost of the CER, including the construction of Dalny city and its harbor amounted to $318,640,236$ golden rubles in 1903. By 1906 this amount had increased to 375 million rubles. In subsequent years, the sum was as big as about 500 million rubles [Melikhov, p. 55-56].

Thanks to the CER in Manchuria there were formed new cities: Dalny, Manchuria and Harbin. Harbin became the heart of Manchuria. Harbin, modern four million centre of the Heilongjiang province, was designed, founded and transformed into the city by Russian engineers, was built by Russian and Chinese builders, and appeared on the geographical map for the first time in 1898 in connection with the construction of the CER. 
There is a traditional view that the number of first Russians and other representatives of the multinational Russian Empire in Harbin in the early years of its existence (1898-1903) was not so great - "hardly two-three thousand people". This is incorrect. The vast scope of railway and urban construction in the initial period demanded a large number of workers. Sparsely populated Northern Manchuria could not satisfy the demand for work force, and the construction of roads soon attracted tens of thousands of Russian and Chinese workers from Russia and Northern China. They settled in this region. It is known that already in 1899 only in Harbin there were about 14 thousand emigrants from the Russian Empire. And they were of different nationalities - Russians, Poles, Jews, Armenians, Georgians and other. Some of them came in the survey parties, the other with builders carts. Thus, Harbin immediately began to take shape of a multinational city. It should be noted that throughout its history, there were no public displays of national antagonism, there were always kept exceptional national and religious tolerance. This was apparently because all natives of Russia felt equally as the pioneers of this isolated and severe region, sharing together all the difficulties of its development, all called themselves "Russians"; also it might have been due to the fact that everybody found some business and did not interfere in each other's lives. Despite the difficulties, the lives of the first residents of Harbin railroad workers were spent in relatively good conditions. Work of qualified specialists was well-paid, they were quickly provided with comfortable state-run apartments, had privileges and benefits.

Harbin had all the conditions, all the necessary prerequisites for rapid and longterm development. It soon became a major transportation hub of a powerful railway, which crossed the whole territory of Manchuria and then transformed into the shortest link of Great
Siberian way. The city was located on the banks of the main water artery of the North Manchuria - Sungari. Chinese settlements of Ashihe, Shuanchenpu, Lalin, Hulan (and later other settlements of grain production created by the rail), surrounding Harbin, were successfully established centers of agricultural, mainly grain production and gave the road a huge number of grain cargoes, which was very important for the CER.

Harbin, conceived of as the administrative center of the alienation zone of the CER, after five years from the date of foundation of the city had about 45 thousand people. Here more than 300 large stone buildings were built (while most of the Siberian and Far Eastern cities were wooden), the first cars, phones, and electric lighting appeared [Krotova].

Russian colony of the city tried to keep the habitual way of life as it was in Russia. Churches and schools were actively built, clubs and associations opened, in 1903 there appeared regularly published first "big" Harbin newspaper "Harbin Vestnik".

By the beginning of the Russo-Japanese war Barga, or Hulunbuir (Western part of Manchuria) and Harbin had turned into relatively large industrial and trading centres playing the role of the rear of the Russian army during the Manchurian campaign.

With the outbreak of war Manchuria saw the flow of traders and entrepreneurs, as well as various kinds of speculators and profiteers, who sought to take advantage of conditions, favorable for the development of enterprises and personal enrichment. Tens of large for that time enterprises of such industrial branches, which previously had not existed or had been little in number, began to open and operate. These include steam roller mills, a variety of plants (distilleries, breweries, tanneries), various factories, mechanical, plumbing, forging workshops and others. The 
"Historical review of the CER" gives the evidence that in 1907 in the Western section of this road, there were just 15,970 Russians, including those in Manchuria - 5,577, in Chgailonor - 1,428, in Hailar-4,375, in Buhedu - 2,767, in Chgalantun1,643. By 1910, this figure had risen to 17,061 people, representing more than $30 \%$ of the total population in Hulunbuir aimag. In the Eastern line there were 7,127 men and women $(3,305$ of them served on the road) and 2004 children. In the Southern line there were 729 men and women (including employees - 503) [Nilus]. In 1910, towns with more than 2 thousand residents (Russian Chinese), included, except Harbin, seven of this kind: Manzhouli, Hailar, Yimianpo, Handaohedzu, Pogranichnaya, Qiqihar, Buhedu station.

Thus, according to calculations based on the available official statistical data, in 1910 the Russian population of Manchuria railroads and villages of the CER, Cossack-peasant population of Ergun Right Banner, Harbin (it should be noted that after the Russo-Japanese war its population decreased) amounted to about 70-75 thousands of people, so Manchuria was even called informally Yellow Russia. Not accidentally, in 1909-1910 at different diplomatic levels there were considered projects of the restrictions on the free border crossing [Datsyshen]. However, the Russian-Chinese border remained open, which is confirmed by the "Instruction for the border surveillance service for divisions, stationed at improving the protection of the state border in the Transbaikal and Primorsky areas of April 30, 1910". The document noted: "Border residents, passing and moving across the border out of the locations of customs institutions and not having trading purposes... should not ... take the responsibility for secret crossing the border and shall pass freely, with mandatory meeting the police requirements set by the local administrative authorities" [Tarasov. P. 200-201].
The construction of the CER had not only a huge positive impact on the development of the economy, population growth and other aspects of public life in Manchuria, but also actively contributed to developing the most extensive and diverse cultural and educational activities in the region. The period of 19061910 was a time of extensive development in Harbin and along the road a network of Russian primary and secondary education schools. The schools opened in significant amount and were headed by the CER educational department. They gave education to Russian and Chinese children. Movement for the construction of schools (including special ones: technical, trade and others) became widespread and allowed to assert, that in this direction - organization of the education system - cultural and educational activities of the Russian people in Manchuria were shown particularly vividly. The school database had exceptional importance. It has gained authority in the following period in the years of exile. The established system of training has allowed Russian children in Manchuria, who grew up in Chinese and Japanese environment, to get Russian education and upbringing, to preserve their language and national identity.

The agrarian question, which formed one of the reasons of unauthorized relocation of the Cossack migrants on the Chinese right Bank of the Argun River from the beginning of the $20^{\text {th }}$ century, was topical throughout the whole of Manchuria. Before the appearance of Russians most of modern grain crops, vegetables, melons and gourds in the region were unknown. The city of Dalny, stations of the Southern line of the CER, the areas of Harbin, Khingansky, Hailar and Ergun Right Banner of the Western line (where, the main branch of agriculture along with plowing was animal husbandry) became centers of Russian agriculture in Manchuria. Along stations of the Eastern 
line - Maoershan, Echo, Mudanjiang, Muling, Pogranichnaya -gardening and bee-keeping were developed. Along with the introduction in agriculture of the region of new progressive technologies, new sorts and completely new to Manchuria crops, the CER created in 1912 Manchurian agricultural company, which paid the most intensive attention to the study of valuable practical experience of Chinese peasants. Fruitful cooperation between the two peoples was the first and foremost made on the grounds of Manchuria in the truest sense of the word. Large Russian livestock farms were at the stations Anda, Sartu, Lamadanczy and further to West - in Chjaromte, Hake, Hailar, Manchuria, Ergun Right Banner.

By the beginning of the World War I in 1914, Manchuria and the CER alienation zone had actively developed. The war also brought into the territory and to the CER rapid economic recovery. In 1914, after the outbreak of hostilities, the border areas of China became centers for procurement of goods for needs of the army. The Russians virtually monopolized trade in meat, fish, fodder, bread, leather and fur, providing the rapid development of trade and industry in Manchuria.

The Russian population of Harbin, at the beginning of World War I was estimated as 43,500 people ( $64.5 \%$ of the total population). If, in 1903 , the Chinese population in a city dominated, by 1914 it, having not decreased in absolute figures (about 28 thousand), was $34.5 \%$ of the total number of inhabitants. The share of industrialists and merchants increased.

"The news about the beginning of the war was unexpected and stirred deep patriotic feeling of the Russian colony in Manchuria. In large settlements there were spontaneous assemblies and manifestations. Officers in Zaamursky District asked the administration persistently to send them to the front as volunteers. Such petitions were submitted to by young civilians too... [Melikhov. P. 301-305]. There was no mobilization of Russian civilians in Manchuria and the CER in this period. We can assume that it was caused by the position of D.L. Horvat (who was the head of the CER since 1903), who was their enemy, supposing the necessity to preserve Russian economic influence in Manchuria. When in the summer of 1915 in Manchuria was declared mobilization, it did not spread on the Russian citizens, permanently residing in the zone, and the employees of the road.

Thus, summing up the second period in the history of Russian population in Manchuria (northeastern China), ending with the revolutionary events of 1917 in Russia, led to the collapse of the Russian Empire and the Civil war, it can be argued that the territory of Russia's eastern neighbor, China, actively developed in this period in legal and illegal ways. The first was associated with the construction and commissioning of the CER, as the Russo-Chinese venture, with Russian-Chinese staff and service, which led to the foundation of many cities and towns of the CER road with mixed RussianChinese population. The latter was associated with the unauthorized transitions of RussianChinese border by Transbaikalian Cossacks and the foundation of their farms and lodges, and then villages in the interfluve of the Argun and Amur - in the area of Ergun Right Banner. And if at the diplomatic level, the Russian-Chinese relations have always been strained, and the official position of the Russians in Manchuria has been seen as a violation of the sovereign rights of China, in contrast to the official level, the relations between Russian and Chinese population were rather friendly and based on sound economic relations. This is confirmed by the absence of serious conflicts and clashes, which allows speaking about quite peaceful relations within a specified period. 


\section{References}

1. Datsyshen, V.G. Essays on the history of Russian-Chinese border in the second half of the $19^{\text {th }}$ - the beginning of the $20^{\text {th }}$ century. Kyzyl, 2001. Mode of access: http://www.tuad.nsk.ru./

2. Krotova, M. (1995). Commercial and industrial life of Harbin in 1906-1914. Problems of the Far East, № 1. P. 126.

3. Kurts, Iu.F. Cossack fortune. Chita, 1995. P. 37.

4. Lukin, A.V. (ed.). Russia and China: four centuries of interaction. History, current state and prospects of development of the Russian-Chinese relations. M.: "Ves' mir", 2013. P. 47

5. Melikhov, G.V. Manchuria far and near. M., 1991. Pp. 23, 55-56, 301-305.

6. Miasnikov, V.S. Qing Empire and the Russian state in the $17^{\text {th }}$ century. M: Nauka, 1980. P. 261.

7. Nilus, Ie.Kh. Historical overview of the CER. Harbin, 1922. P. 621.

8. RSHA (Russian state historical archive). F. 323. Inv. 4. Delo 5. List 1-2.

9. RSHA (Russian state historical archive). F. 796. Inv. 179. Delo 1277. List 1.

10. Russian-Chinese contract and legal acts. 1689-1916. M, 2004. P. 28.

11. Serebrennikov, I. I. (1925). Essays on the economic geography of China. Bulletin of Asia. № 53. P. 5.

12. Sladkovskii, M. I. History of trade and economic relations of the peoples of Russia with China (until 1917). M: Nauka, 1974. P. 123.

13. Tarasov A.P. Transbaikalia and China: experience of analysis of international relations. Chita: RISZabGPU (Transbaikal State Pedagogical University), 2003. Pp. 194, 198, $200-201$.

14. Manakin,M.Description of thejourney from Old-Zuruhajtuevsky guard up to Blagoveshchensk. Zapiski Chitinskogo otdeleniia Priamurskogo otdela IRGO (Notes of the Chita branch of the Amur Department of the IRGS). Vol. 3-4. 1988, 1901. P. 4. 


\section{Маньчжурия и полоса КВЖД}

\section{как исторически сложившиеся к 1917 году \\ зарубежные центры русского расселения \\ на территории Северо-Восточного Китая}

И.В. Чапыгин

Иркутский государственный университет Россия, 664003, Иркутск, ул. Карла Маркса, 1

В статье рассматриваются Маньчжурия и полоса КВЖД как исторически сложившиеся к 1917 г. зарубежные центры русского расселения на территории Северо-Восточного Китая. Автор путем краткого анализа взаимоотношений России и Китая в период XVII - начала XX в. показывает этапь активного освоения территории соседнего государства российскими подданными в указанный период.

Ключевые слова: Маньчжурия, Северо-Восточный Китай, казаки, государственная граница, договор, Харбин, КВЖД.

Научная специальность: 07.00.00 - исторические науки. 